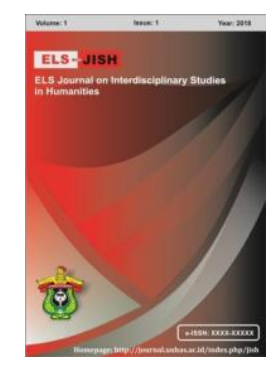

ELS-JISH

ELS Journal on Interdisciplinary Studies on Humanities

Volume 3 Issue 3, 2020

ISSN (print) : 2621-0843

ISSN (online) : 2621-0835

Homepage : http://journal.unhas.ac.id/index.php/jish

\title{
Unrecorded Idiomatic Expressions of Sikka Krowe Dialect In Flores Island East-Nusa Tenggara
}

\author{
Maria Nelciana Mua Koban ${ }^{1 *}$, Darmawan ${ }^{2}$, Rikardus Nasa ${ }^{3}$ \\ ²wawanlabira@gmail.com
}

\begin{abstract}
The aim of this study is to identify types of idioms found in Sikka Krowe dialect in Nita sub district of Sikka regency. The data were taken through interviews and observations. Qualitative method was used in analyzing the data. As the result, the type of Idiomatic expressions was found. Those idiomatic expressions are divided into two types; they are classified base on the closeness of the elements and base on the elements of formulation. There are 9 full idioms and 6 partial idioms in the closeness of the elements classification and 10 idioms with part of body: 4 idioms with the word senses, 2 idioms with color; 1 idiom with the names of object name; 4 idiom with animal name; 1 idiom with lant parts, 2 Idiom numeralia, 1 idiom of verba, 1 idiom of nouns, 1 idiom of adjectives. Meanwhile, the meaning of idiomatic expressions was based on the context of the dialogues and the narratives in Sikka Krowe dialect in Nita sub district of Sikka regency.
\end{abstract}

Keywords: Dialect, Idiomatic expression, Sikka kkrowe dialect.

How to cite: Koban, M., Darmawan, \& Nasa, R. (2020). Unrecorded Idiomatic Expressions of Sikka Krowe Dialect In Flores Island East-Nusa Tenggara. ELS Journal on Interdisciplinary Studies in Humanities, 3(3), 459-466. DOI: https://doi.org/10.34050/elsjish.v3i3.10534

\section{Introduction}

Every place in Indonesia has its own culture. One of them is Sikka Krowe cultures of Maumere, Flores-East Nusa Tenggara. The majority of the population are Sikka Krowe people who speak Sikka language in the Sikka dialect, Krowe dialect and Tana a'l dialect. Besides of Sikka people, residents of Sikka disrict are also Lio people, people of Palu'e, people of South Sulawesi, Tianghoa and various tribes in East-Nusa Tenggara and others indonesians.

Wurm and Hattori (1983) stated that Sikka krowe dialect is an Austronesian language includes in the Flores-Lembata (Lomblen) Subgroup, Timor Area Group of the Austronesia languages of the Lesser Sunda Islands. Sikka Krowe is an ethnic group of people that use Sikka Krowe dialect who inhabit specific area in the central hills of Sikka regency such as Sikka Lela, Nita, Koting, Nelle Baluele, Habi, Ili, Wetakara, Bola, Wolomude, Wolonwalu, Doreng and Halehebing. The other dialect is Sikka Muhan dialect is used by people in the east of Sikka regency

1,2,3 IKIP Muhammadiyah Maumere, Indonesia 
around Kringa and Werang; Lio language is used by people in the west of Sikka regency around Mblengu, Mego, Nualolo, and Bu; Palu'e language is used by people who live in Palu'e island in the north of Sikka regency around Lajangawawi, Suria, Kimalaja, piwa and Uwi muri; Bajo language is used by people the comunity that came from south of sulawesi

According to oral traditional for generations, once the name of "Nita" comes from the name of a large tree that grows in the middle of the village called Nita tree. In the ancient times, people made shelters to take a rest and even started using it as a market which people used mother tongue in daily life communication so called Sikka Krowe dialect.

One of the characteristics of language, but not all native speakers are aware of is idiom. Basically, idiom is the combination of words with words and creates a new meaning and most of them are figurative meaning. The use of this idiom is intentionally carried out primarily to express something indirectly to the other person, be it to praise, insinuate, mock, and express feelings of sadness, disappointment, excitement and so on. In fact, every language in the world has its own idiom.

Hartati (2019) stated that the function of the idiom is actually deliberately carried out by someone to express an intention which is a word or language that is outside the actual context that is easier to understand or understood by the interlocutor to avoid misunderstanding between the speaker and listener. In general the use of idioms has the function of smoothing speech, showing excessive meaning and shortening speech. Aboulalaei (2015) stated that people use idioms to make language richer and more displayed and to be able to express subtle meanings or intentions. So, idiom is a cultural expression that is often found in the language systems of each ethnic or community. The meaning of idiom can be literal meaning, idiomatic meaning and cultural meaning.

Like the notion of the language in general, Sikka Krowe dialect also has idioms for communicating and interacting for the Sikka community as a language inherited from generation to generation. This idiomatic expressions has a set of important functions, namely as a marker of identity that is a differentiator with other ethnicities on the area of Sikka Krowe distribution. Apart from being a unifying language for its speakers, Sikka Krowe dialect with a style that is different from the others everyday language called "Peleng pata" $n$ or idiomatic expression

Idiomatic expression is a kind of complex lexical item and its meaning cannot be inferred from its parts. Idiomatic expression is special expression consist of a series of word or phrase in English which has different meaning in literally or word-for-word. Newmark (1988) stated taht idiomatic translation: it reproduces the 'message' of the original but tends to distort nuances of meaning by preferring colloquialisms and idioms where these do not exist in the original.

In some senses, idiomatic expression is the reflection of the environment, life, and historical culture of the native speakers and is closely associated with their innermost spirit and feelings. They are commonly used in all types of language, informal and formal, spoken and written. As idioms are important part of languages, understanding of a language requires understanding of its idioms and the tactics for idiom translation. 
Idiom is a language unit (can be words, phrases, and sentences) whose meaning cannot be predicted from the elements' lexical meaning or grammatical meaning (Chaer 1990, p.76). Based on the definition, idiom has two characteristics, (i) a language unit that can be in the form of a word, a phrase, and a sentence and (ii) idiomatic meaning cannot be predicted only from its lexical or grammatical meaning of its element such as t. The word burung (bird) in kabar burung (rumors), plural patah hati (broken-hearted), phrase dari hati ke hati or 'talking directly heart to heart', clause membakar hati (to burn the heart) 'to cause somebody jealous', and sentence terbuka hatinya (to open the heart) or 'realizing something' were included as idioms because the meaning cannot be predicted from its lexical or grammatical units.

There are some literatures have discussed idioms in Bahasa Indonesia, such as Sari (2010), Abdul Khak (2011), and Suyatno (2012). Sari (2010) reviewed idioms in the novel Sang Pemimpi from the point of grammatical units, categories, and types of idioms. Abdul Khak (2011) talked about idiom in Bahasa Indonesia in terms of structure and meaning. Suyatno (2012) studied idioms in the Indonesian language extensively, namely the constituent elements, reference sources, scope of use, patterns of meaning, culture, use motives, and the phenomenon of its development.

The other literatures in Bahasa Indonesia studied specific aspects were Baryadi (2017) and Haiyan (2016). Baryadi (2017) researched the idioms containing verbs in bahasa Indonesia from the aspect of verb form and any other word category that fit with verbs to form an idiom. Haiyan (2016) compared animal idioms in Mandarin and Bahasa Indonesia from its definition, origin, linguistic aspect, and cultural anthropology.

From those literatures reviewed, it is revealed that there has been no research on Idiomatic expression in Sikka Krowe dialect. There are some famous Sikka Krowe idiom expressions for examples: *Blatanblaur consists of blatan and blaur. In Indonesia, blatan is dingin and blaur is katak. This idiomatic means sangat dingin and in English very cold. *Waerumang consists of wae and rumang. In Indonesia, wae is muka and rumang is gelap. This compound means orang gila in English crazy. The writer intends to study Idiomatic expression in Sara Krowe dialect as a native speaker of Sikka krowe dialect. The purposes are (1) in order to maintenance the Sara Krowe to be our language assets as inheritance of culture (2) to keep the identity of Sara Krowe dialect.

\section{Method}

This research took place in Sikka regency and focused on the analysis of idiomatic expressions of Sikka Krowe dialect in Nita sub district of Sikka regency. So in this study the writer will use descriptive-qualitative research, which means, examines participant with strategies that are interactive and flexible. Qualitative research is aimed at understanding social phenomena from participants angles thus the meaning or undestanding of qualitative research that is use to examine the condition of object. Natural where researchers are key instruments (Darmawan,2019).

This research was done through the following steps: collecting the data, analyzing the data, and presenting the result of the data analysis. The data were obtained from 50 adult native speakers of Sikka Krowe language through interview and observation method. The data were analyzed using distributional method. Distributional method is a data analysis method whose instrument was 
part of the language itself (Sudaryanto, 2015, p.15). Distributional method applied three techniques, they are: mark-up technique, paraphrase technique, and expansion technique. Those three techniques are used to identify idiomatic expression. The first technique was mark-up technique to identify the transitive verb has me- $(\mathrm{N})$ - as its prefix, for example, memberi, melapangkan, and melukai. The second one is paraphrase technique; to figure out that the transitive verbs are equivalent with the transitive verb that has prefix di-, for example, diberi, dilapangkan, and dilukai. The third was the expansion technique; it is proven that transitive verb is indeed demanding an object which in this case is hati itself so it forms idioms memberi hati, melapangkan hati, and melukai hati.

The equivalence method is a method which the instrument is outside and regardless to a language that correspond (Sudaryanto, 2015). This method was applied as a referential of the source is a referent or a fact that was shown by its language or language referent. It is used to identify the meaning of idioms containing hati and a transitive verb.

\section{Results}

The idiomatic expression found in Sikka Krowe dialect can be presented in the following tables.

a. In the terms of the closeness of the elements in shaping meaning, there can be distinguished two types of idioms namely full idioms and partial idioms (Chaer, 1993)

1) Full idiom

Full idiom is an idiom whose elements as a whole are one entity with one meaning.

Example ;

\begin{tabular}{|c|c|c|c|}
\hline 1 & $\begin{array}{l}\text { Deri } \\
\text { gete }\end{array}$ & Deri (sit) + gete (big) & $\begin{array}{l}\text { People who choose not to have a } \\
\text { partner or not get married for the } \\
\text { rest of their lives. }\end{array}$ \\
\hline 2 & $\begin{array}{l}\text { Gum } \\
\text { an } \\
\text { gete }\end{array}$ & Guman (night) + gete (big) & Midnight \\
\hline 3 & $\begin{array}{l}\text { Lahi } \\
\text { lekan } \\
g\end{array}$ & $\begin{array}{l}\text { Lahi (tidying or repairing) + } \\
\text { Lekang (arge) }\end{array}$ & $\begin{array}{l}\text { Solve a problem together as fairly } \\
\text { as possible. }\end{array}$ \\
\hline 4 & $\begin{array}{l}\text { Bano } \\
\text { blon }\end{array}$ & Bano (go away + blon (long) & $\begin{array}{l}\text { I especially those love to travel } \\
\text { out of the house }\end{array}$ \\
\hline 5 & $\begin{array}{l}\text { Gi'it } \\
\text { meno } \\
\text { ng }\end{array}$ & $\begin{array}{l}\text { Gi'it (bite) + menong (looking } \\
\text { back) }\end{array}$ & $\begin{array}{l}\text { A family gathering one day before } \\
\text { an event or party }\end{array}$ \\
\hline 6 & $\begin{array}{l}\text { Tibo } \\
\text { lame } \\
n\end{array}$ & $\begin{array}{l}\text { Tibo (a developing } \\
\text { body) + lamen (male) }\end{array}$ & Youth \\
\hline
\end{tabular}




\begin{tabular}{clll}
\hline 7 & $\begin{array}{l}\text { Lero } \\
\text { wulan }\end{array}$ & Lero (sun) + wulan (month) & The upper realm \\
\hline 8 & $\begin{array}{l}\text { Sako } \\
\text { seng }\end{array}$ & Sako (hoe) + seng (money) & Mutual cooperation \\
\hline & $\begin{array}{l}\text { Rega } \\
\text { ng }\end{array}$ & Regang (meet) + Nita (village & Nita market \\
& Nita & & \\
\hline
\end{tabular}

2) Partial idiom

Partial idiom are idiom whose elements have their own lexical meaning.

Example ;

\begin{tabular}{llll}
1 & Ta'in gete & Ta'in (stomach) + gete (big) & Pregnant \\
\hline 2 & Waen rumang & Waen (face) + rumang (dark) & Madman \\
\hline 3 & Waen bura & Waen (face) + bura (putih) & Lazy bones \\
\hline 4 & U'an tena & U'an (work) + tena (do) & $\begin{array}{l}\text { People in daily life } \\
\text { became a weaving }\end{array}$ \\
\hline 5 & Du'a gete & Du'a (woman) + gete (big) & Mother \\
\hline 6 & Kula babong & Kula (kidding) + babong (tell) & Discussion \\
\hline
\end{tabular}

b. Based on the elements of formulation

Pateda (1989) stated that the type of idiom based on the elements that make it has seven part, namely as follows ;

1) Idiom with part of body

Are idioms that use the elements forming the human body.

\begin{tabular}{llll}
\hline 1 & Me natar & Me (child) + natar (village) & Fainted \\
\hline 2 & Irun wolong & Irun (nose) + wolon (hill) & Pointed noise \\
\hline 3 & Waen rumang & Waen (face) + rumang (dark) & Madman \\
\hline 4 & Waen glet & Waen (face) + glet (dizzy) & Crazy \\
\hline 5 & Waen rua & Waen (face) + rua (two) & Ugly trait \\
\hline 6 & Waten gahu & Waten (heart) + gahu (hot) & Heartache \\
\hline 7 & Ta'in gete & Tain (stomach) + gete (big) & Pregnant \\
\hline 8 & Waen inga & Wae (face) + inga (bright) & Mindful \\
\hline 9 & Waten kesik & Waten (heart) + kesik (small) & Kind-hearted \\
\hline 10 & Waten gete & Waten (heart) + gete (big) & Envy \\
\hline
\end{tabular}

2) Idiom with the word senses 
Idiom consistng of five senses is an idiom formed from the activities of the five senses responses.

\begin{tabular}{llll}
1 & Waten hala & Waten (heart) + hala (wrong) & Bad feeling \\
\hline 2 & Ta'in aning & Ta'in (stomach) + aning (wind) & Bload \\
\hline 3 & Aru watu & Aru (chin) + watu (stone) & Stubbron \\
\hline 4 & Ta'in aning & Ta'in (stomach) + aning (wind) & Bloated \\
\hline
\end{tabular}

3) Color name idiom

That idiom use color names as their lexical elements

\begin{tabular}{llll}
1 & Waen merak & Waen (face) + merak (red) & Shy \\
\hline 2 & Bura wulan & Bura (white) + wulan (moon) & Albino \\
\hline
\end{tabular}

4) Idiom with the names of object

Idioms that use he name of natural objecs as their lexical elements.

Example :

1 Tawu korak Tawu (a place of the said kind of One type of fruit which is used to store foo) + children's games korak (shell) or cooking games

5) Idiom with animal names

Are idioms whose lexical elements are related to animal, thir parts and certain characteristics that are compared to human traits that appear to the elements of the animal's body.

Example;

\begin{tabular}{llll}
1 & Blatan bla"ur & Blatan (cold) + bla'ur (frog) & Very cold \\
\hline 2 & Ko'at pitek & $\begin{array}{l}\text { Ko'at (grasshopper) + pitek earache } \\
\text { (flick) }\end{array}$ \\
\hline 3 & Manu sama & $\begin{array}{l}\text { Manu (chicken) + sama } \\
\text { (same) }\end{array}$ & $\begin{array}{l}\text { One type of cold disease } \\
\text { that never improves and } \\
\text { causes injury to the inside of } \\
\text { the nose }\end{array}$ \\
\hline 4 & Uru widin & Uru (disease) + widin (goat) & Epilepsy \\
\hline
\end{tabular}

6) Idiom with lant parts

Are idioms whose lexical elements are formed from the names of plantsor part of plans

Example

$$
1 \text { Air'oun } A i \text { (kayu) + r'oun (daun) Vegetables }
$$

7) Idioms that are formed from various classes of words

Idioms whose formation elements are number, verbs, nouns, adverbs and adjectives. 
a) Idiom numeralia

Example;

i. waen rua; waen (face) + rua (two) = ugly trait

ii. ha tali; ha (one) + tali (string) = two pieces or used when two fruits are tied together

b) Idiom of verba

Example; - ma mai; $\quad$ ma (go $)+$ mai (came) $=$ when someone goes from somewhere he is expected to return again.

c) Idiom of nouns

Example ; - Aru watu; aru (chin) + watu (stone) = stubborn

d) Idiom of adjectives

Example ; - na'i waten; na'i (save) + waten (heart) = revenge

\section{Conclusion}

From the findings and discussion, the researchers found 42 (forty two) idiomatic expressions classification in Sikka Krowe dialect and the most dominant of idiomatic expressions was 11 part of body idiomatic expressions $(26,19 \%)$ and the rarely is Idiom of adjectives and has been found of the research of the research is 1 idiom $(2,38 \%)$.

\section{Acknowledgments}

The researchers wish to express her appreciation to many individuals for their contributions. The researcher is fully aware that without them this work would not have been possible. In this best opportunity, the researcher would like to express her deepest gratitude to Haji Abdul Natsir Roja, S.H, M.Pd as the Rector of Muhammadiyah Maumere of Teacher Training Institute and Educational Science Muhammadiyah Maumere, Antonius M.K Naro, S.Pd, M.Ed as the Chairman of English Department.

\section{References}

Abdul khak, M. (2011). Idioms in Indonesian : structure and meaning. Jurnal Widyaparwa, 39(2), 144-154

Baryadi, I. P. (2013). March. Idioms with Verbs in Idonesian language. Synthesis. Vol. 7:46-82

Darmawan, (2019). The Comparison of the Phonological Features of Sikka Language and English, Vol. 4, No. 1, 2019, 64-72 DOI: 10.22236/JER_Vol4Issue1

Ferdowsi, S. (2013). Translation of Idiomatic Expressions in Subtitling. The Iranian EFL Journal, 9(4), 346-365

Haiyan, H. (2016). Idiom Comparison it has the names of animals in language mandarin and Indonesian. Graduate Program Gadjah Mada University's Cultural Sciences Yogyakarta. 
Sari, K. (2010). Idioms in Dreamer Novel by Andrea Hirata. Thesis Literature Study Program Indonesia, Indonesian literature Deparment, Faculty of Ltters, Sanata University Dharma, Yogyakarta.

Suyatno, M. (2012). Idioms in Indonesian. Dissertation. Yogyakarta: Postgraduate Program in the Faculty of Science Culture of Gadjah Mada University.

Sudaryanto.(2015), Methods and Various techniques of language analysis. Yogyakarta: sanata Dharma University Press.

Wijana, I Dewa Putu. (2016). Linguistic Method: Identification of Lingual Units. Yogakarta: A. Com press.

Pareira D. D., \& Alexius B. Pareira. (2008). Hikayat Kerajaan Sikka. Penerbit Leda lero Maumere. 